\title{
Media Pembelajaran PJOK Berbasis Audio Visual pada Materi Shooting Bolabasket
}

\author{
Kadek Maha Ari Pranata ${ }^{1}$, H. Wahjoedi², Kadek Yogi Parta Lesmana ${ }^{3}$
}

1,2,3 Program Studi Penjaskesrek, Universitas Pendidikan Ganesha, Singaraja, Indonesia

\section{ART ICLE INFO}

Article history:

Received February 24, 2021

Revised February 26, 2021

Accepted July 07, 2021

Available online July 25, 2021

Kata Kunci:

Pengembangan, Media

Pembelajaran, Shooting

Bolabasket

Keywords:

Development, Learning Media

Basketball Shooting

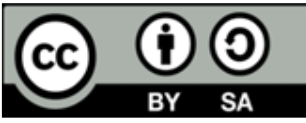

This is an open access article under the CC BY-SA license.

Copyright () 2021 by Author. Published by Universitas Pendidikan Ganesha.

\begin{abstract}
A B S T R A K
Kurangnya penggunaan media pembelajaran selama prose pembelajaran menyebabkan rendahnya motivasi siswa dalam belajar sehingga mengakibatkan rendahnya hasil belajar siswa. Tujuan dari penelitian ini adalah mengembangkan produk media pembelajaran PJOK berbasis audio visual materi shooting bolabasket kelas XI SMA Negeri 2 Singaraja Tahun Pelajaran 2020/2021. Penelitian ini merupakan penelitian pengembangan. Model pengembangan yang digunakan adalah model Borg \& Gall hanya sampai lima tahap, yaitu: Study pendahuluan, tahap perencanaan, tahap pengembangan, produk awal penelitian, tahap uji validitas ahli dan revisi produk, validasi dan penyebaran produk media pembelajaran. Prosedur validasi pengembangan media pembelajaran ini yaitu uji validitas ahli isi/materi pembelajaran, uji validitas ahli desain media pembelajaran, dan uji validitas ahli media pembelajaran. Data dianalisis menggunakan teknik analisis deskriptif kuantitatif. Pengumpulan data dilakukan menggunakan metode kuesioner secara online melalui aplikasi Google Drive dan WhatsApp. Hasil analisis data berdasarkan tanggapan ahli isi/materi pembelajaran memperoleh presentase $94,6 \%$ dengan kualifikasi sangat baik. Ahli media pembelajaran memperoleh presentasi 92\% dengan kualifikasi sangat baik. Ahli desain media pembelajaran memperoleh presentase $93 \%$ dengan kualifikasi sangat baik. Sehingga dapat disimpulkan bahwa media pembelajaran PJOK berbasis audio visual pada materi shooting bolabasket kelas XI SMA Negeri 2 Singaraja Tahun Pelajaran 2020/2021 dikatakan layak untuk digunakan dalam proses pembelajaran.
\end{abstract}

\section{A B S T R A K}

The lack of use of learning media during the learning process causes low student motivation in learning, resulting in low student learning outcomes. The purpose of this research is to develop PJOK learning media products based on audio-visual materials for basketball shooting class XI SMA Negeri 2 Singaraja for the 2020/2021 academic year. This research is development research. The development model used is the Borg \& Gall model only up to five stages, namely: preliminary study, planning stage, development stage, initial product research, expert validity test stage and product revision, validation and dissemination of learning media products. The validation procedure for developing learning media is testing the validity of the content/learning material experts, testing the validity of learning media design experts, and testing the validity of learning media experts. Data were analyzed using quantitative descriptive analysis techniques. Data collection was carried out using an online questionnaire method through the Google Drive and WhatsApp applications. The results of data analysis based on expert responses to content/learning materials obtained a percentage of $94.6 \%$ with very good qualifications. Learning media experts get a presentation of $92 \%$ with very good qualifications. Learning media design experts get a percentage of $93 \%$ with very good qualifications. So it can be concluded that the audio-visual-based PJOK learning media on basketball shooting material for class XI SMA Negeri 2 Singaraja in the 2020/2021 academic year is said to be feasible to use in the learning process. 


\section{PENDAHULUAN}

Pendidikan merupakan usaha terencana yang dilakukan manusia untuk merubah kepribadian serta mengembangkan potensi yang dimilikinya demi kelangsungan hidup yang lebih baik. (Parwati, Suryawan, \& Apsari, 2018; A. Setiawan \& Rahmat, 2018). Pendidikan merupakan proses perubahan atas hasil belajar yang didapat yang mencakup segala aspek kehidupan untuk tercapainya suatu tujuan tertentu yang diinginkan (Pane \& Dasopang, 2017). Pendidikan memegang peran penting dalam kehidupan peserta didik dan pendidikan diharapkan mampu membimbing peserta didik itu sendiri agar bisa lebih baik dan bermartabat. Pendidikan erat hubungannya dengan proses pembelajaran, karena pada dasarnya adalah suatu usaha yang dilakukan peserta didik guna memperoleh suatu perubahan-perubahan tingkah laku menuju pendewasaan diri secara menyeluruh serta ditandai dengan adanya perubahan dalam ranah kognitif (pengetahuan), ranah psikomotorik (keterampilan), dan ranah afektif (sikap), dalam rangka menciptakan suatu perubahan dalam diri peserta didik menuju ke hal yang lebih baik.

Proses pembelajaran merupakan perkembangan peserta didik melalui potensi yang dimiliki dari adanya proses belajar harus dilakukan secara menyeluruh dan terencana agar hasil yang diinginkan sesuai dengan tujuan pembelajaran. Pembelajaran sangat erat kaitannya dengan proses belajar. Belajar merupakan tahapan mengumpulkan pengetahuan secara terencana yang terjadi selama hidupnya (Pane \& Dasopang, 2017). Belajar merupakan aktifitas mental untuk memperoleh suatu perubahan sikap yang positif melalui kegiatan yang telah dialami dan yang merubah aspek kepribadian diri seseorang (Husmah, Pantiwati, Restian, \& Sumaryono, 2016; Andi Setiawan, 2017) Pertanda dari peserta didik sudah belajar adalah adanya perubahan perilaku didalam diri peserta didik yang menjadi lebih baik. Perubahan perilaku tersebut berupa perubahan yang bersifat kognitif (pengetahuan), psikomotorik (keterampilan), dan afektif (sikap). Guru memegang peran penting dalam proses pembelajaran. Tugas guru seorang guru bukan hanya menyampaikan pengetahuan dan pemahaman dari suatu materi, namun saat ini seorang guru harus mampu memberikan pendidikan karakter kepada peserta didik, dan perlu memperhatikan aspek-aspek pembelajaran melalui suatu media dan model pembelajaran yang mendukung terwujudnya pengembangan potensi peseta didik (Suranti, Gunawan, \& Sahidu, 2016). Desain pembelajaran yang baik ditambah dengan kreatifitas guru dalam mengajar akan senantiasa membantu peserta didik dalam proses belajar yang akan mengarahkan pada penguasaan materi yang diberikan. Aktivitas pembelajaraan merupakan inti dari Pendidikan di sekolah khususnya pembelajaran pendidikan jasmani, olahraga dan kesehatan (PJOK),

Pendidikan jasmani sendiri adalah program pendidikan yang memberikan pengaruh besar terhadap perubahan dan perkembangan peserta didik secara keseluruhan. Pendidikan jasmani olahraga dan kesehatan ditekankan guna meningkatkan perkembangan jasmani, perkembangan rohani, dan kemampuan gerak motorik yang sepadan (Mashuri, 2017; Sudirjo, Susilawati, Lengkana, \& Alif, 2019) Pendidikan jasmani adalah hal yang penting dalam proses pendidikan dari semua kegiatan belajar yang memanfaatkan aktivitas jasmani yang diperuntukan untuk memperoleh hasil belajar yang optimal. Dapat diartikan kalau pendidikan jasmani sebagai presentase integral dari suatu sistem pendidikan yang secara keseluruhan menggunakana aktivitas jasmani yang dirancang secara rapi dan terencana serta terarah guna meningkatkan kualitas individu (Wahjoedi, 2017). Dilihat dalam bidang kesehatan, pendidikan jasmani mengutamakan pada kesehatan jasmani yang diutamakan pada keadaan jasmaniah individu sebagai individu yang bugar dan sehat, yang didapat melalui aktivitas motorik yang terencana dan teratur serta mendapat bantuan dari makanan yang dikonsumsi (Iqbal, 2015; Lesmana, 2014; Sudirjo et al., 2019). Pentingnya olahraga yang di terapkan di sekolah dapat diamati dari maksud proses kegiatan pembelajaran PJOK, dari aspek afektif, kognitif dan psikomotorik (Hanief, Mashuri, \& Subekti, 2018; Husmah et al., 2016). Pembelajaran pendidikan jasmani, olahraga dan kesehatan (PJOK) terdapat beberapa materi pelajaran yang tertuang dalam silabus dan kurikulum yang berlaku disekolah, salah satunya materi bolabasket.

Permainan bolabasket merupakan permainan olahraga bola besar yang menjadi materi pelajaran wajib bagi peserta didik. Permainan bolabasket ialah suatu permainan olahraga bola besar yang dimainkan secara berkelompok yang terdiri dari dua kelompok tim yang terdiri dari lima orang yang saling bertanding untuk bisa mendapatkan point dengan cara memasukkan bola ke dalam sasaran (W. A. F. Dewi, 2020; Heri Rustanto, 2017). Pada dasarnya dalam materi permainan bolabasket memiliki beberapa teknik dasar yang harus dipahami (Candra, 2017). Teknik dasar permainan bola basket meliputi sikap tangan atau teknik memegang bola, menggiring bola (dribbling), melempar bola (passing and catching), menembak (shooting), rebound dan pivot. (Adresta \& Candra, 2020; Prameswara, 2019). Shooting merupakan teknik dalam permainan bola basket yang dilakukan dengan cara menembakkan bola ke arah ring dengan tujuan mencetak point sebanyak-banyaknya (Budi \& Prihanto, 2014; Yuliana, Peni \& Syam Tuasikal, 2020). Dalam permainan bola basket, shooting adalah teknikpermainanyang memiliki peran yang sangat sangat penting. Pentingnya keterampilan shooting dalam permainan bola 
basket maka, melalui berbagai teknik, metoda, dan strategi pembelajaran yang digunakan oleh guruharus dapat diterapkan untuk dapat meningkatkan keterampilan shooting yang dimiliki oleh siswa (Sampurno \& Qohhar, 2020).

Namun berdasarkan hasil observasi awal yang peneliti lakukan di SMA Negeri 2 Singaraja pada peserta didik kelas XI yang berjumlah 286 peserta didik, proses pembelajaran PJOK dilaksanakan secara daring (dalam jaringan) melalui aplikasi google classroom dan aplikasi google meet. Hal ini dikarenakan keadaan pandemi covid-19 yang melanda Indonesia, maka seluruh peserta didik dan seluruh instansi pendidikan dianjurkan untuk belajar dan bekerja dari rumah. Berdasarkan hasil wawancara peneliti dengan guru PJOK kelas XI di SMA Negeri 2 Singaraja beliau berpendapat bahwa proses pembelajaran secara daring melalui aplikasi google classroom membuat semangat dan minat belajar peserta didik menjadi menurun yang menyebabkan hasil belajar peserta didik pada mata pelajaran PJOK khususnya pada materi teknik dasar shooting dalam permainan bolabasket menjadi menurun. Tidak hanya itu, beliau juga berpendapat bahwa aktivitas fisik dalam pembelajaran PJOK menjadi terbatas (Jalil, Ngabekti, \& Susilowati, 2016). Selain itu masalah yang dialami oleh siswa dalam pembelajaran bola basket yaitu karena jumlah peralatan yang minim serta pembelajaran berpusat pada guru karena kurangnya variasi model dan gaya mengajar yang diterapkan (Saputra, Kanca, \& Lesmana, 2017). Hal ini akan berpengaruh terhadap hasil belajar siswa. Rendahnya aktivitas belajar berpengaruh terhadap kemampuan pengetahuan siswa. Peneliti juga melakukan wawancara kepada peserta didik kelas XI di SMA Negeri 2 Singaraja, dia berkata bahwa dalam proses pembelajaran PJOK guru kurang menerapkan media pembelajaran yang kreatif, guru hanya memberikan tugas membuat video dan tugas esai, serta dalam penyampaian materi yang diberikan guru PJOK guru hanya memberikan link video yang diambil dari YouTube.

Penyelesaian masalah-masalah pembelajaran jasmani diperlukan adanya sebuah inovasi dan kreativitas dalam mengatasi berbagai permasalahan tersebut. Pengembangan media pembelajaran yang kreatif dan inovatif dalam pembelajaran PJOK menjadi salah satu cara untuk mengatasi permasalahan tersebut. Media pembelajaran yaitu media yang menyampaikan informasi perantara yang diperuntukan menyampaikan materi (Khozain \& Mumaisaroh, 2020; Putra, Kanca, \& Suwiwa, 2017). Media pembelajaran berdampak positif bagi guru dan peserta didik karena mampu menciptakan proses pembelajaran yang efektif dan efesien karena mengarahkan konsentrasi peserta didik pada isi pelajaran melalui media pembelajaran yang digunakan (Ashfahany, Adi, \& Hariyanto, 2017; Fauzi \& Rosliyah, 2020) (Fatoni, Suroto, \& Indahwati, 2017). Salah satu media pembelajarn yang dapat digunakan adalah media pembelajaran bebbasis audio visual. Media pembelajaran berbasis audio visual menjadi salah satu media pembelajaran yang bisa dimanfaatkan dengan baik serta didalamnya terdapat tahapan belajar yang sistematik dan terperinci. Media pembelajaran audio visual adalah produk dan penggunaan materi pembelajaran yang penyerapannya melalui penglihatan dan pendengaran serta tidak seluruhnya tergantung kepada pemahaman kata atau simbol yang serupa (Hidayati, 2016:32). Keuntungan dari media pembelajaran berbasis audio visual ini adalah media pembelajaran ini mampu membantu tenaga pendidik dalam menyampaikan materi pembelajaran dengan desain yang menarik serta memberikan inovasi dalam pembelajaran yang bisa diputar berkali - kali untuk menjadikan peserta didik lebih memahami dan mengerti materi yang dipaparkan oleh guru. Peneliti mengembangkan media pembelajaran PJOK berbasis audio visual pada materi shooting bolabasket ini dikarenakan: (1). Membantu peserta didik guna menumbuhkan minat dan motivasi dalam belajar peserta didik dalam proses pembelajaran PJOK. (2). Pedia pembelajaran audio visual sangat sesuai digunakan dalam proses pembelajaran PJOK yang dilaksanakan secara daring karena media pembelajaran PJOK berbasis audio visual ini dapat diputar berulang kali sehingga proses pembelajaran bisa dipelajari diluar jam pelajaran. (3). Pengembangan media pembelajaran berbasis audio visual ini dapat membantu guru PJOK untuk bisa mengembangkan media pembelajaran yang kreatif dan inovatif guna supaya materi pembelajaran bisa tersampaikan dengan jelas kepada peserta didik.Pemilihan Pengembangan Media Pembelajaran PJOK berbasis audio visual pada penelitian ini juga dikuatkan oleh hasil penelitian dari peneliti sebelumnya yang menggunakan media pembelajaran yang sama antara lain peneltian oleh 1) (Febryanto, 2015) yang menunjukkan media pembelajaran audio visual dapat meningkatkan hasil belajar siswa, 2) Hasil penelitian oleh (Rupawati, Noviani, \& Ariyanto, 2017) yang menunjukkan bahwa Penerapan Media Pembelajaran Audio Visual dapat meningkatkan hasil belajar ekonomi siswa kelas XI IPS 12 SMAN 5 Surakarta Tahun ajaran 2016/2017. 3) Penelitian oleh (Adresta \& Candra, 2020) yang menunjukkan peningkatan pembelajaran shooting free throw bola basket melalui media audio visual pada siswa kelas $\mathrm{X}$ MIPA1SMA Negeri 1Rengat Barat dengan peningkatan sebesar (31.43\%) 4) Penelitian oleh (Sokheh, Wahjoedi, \& Suwiwa, 2017) yang menunjukkan bahwa media video pembelajaran dengan model ADDIE materi passing bola basket dapat dikatakan valid dan dapat digunakan untuk pembelajaran atau penelitian lebih lanjut. 
Adapun yang membedakan antara penelitian ini dengan penelitian pengembangan sebelumnya yakni pada pemilihan media pembelajaran yang dikembangkan serta jenis permainan yang dipilih. Penelitian ini berfokus pada Media Pembelajaran PJOK Berbasis Audio Visual Pada Materi Shooting Bolabasket. Dengan menggunakan media pembelajaran audiovisual diharapkan dapat memudahkan guru dalam mengajar di masa pandemic seperti sekarang. Tujuan yang hendak dicapai melalui penelitian ini adalah untuk mendeskripsikan rancang bangun pengembangan media pembelajaran PJOK berbasis audio visual pada materi shooting bolabasket kelas XI SMA Negeri 2 Singaraja tahun pelajaran 2020/2021 dan untuk mengetahui tanggapan ahli isi materi, ahli media pembelajaran, dan ahli desain pembelajaran terhadap pengembangan media pembelajaran PJOK berbasis audio visual pada materi shooting bolabasket kelas XI SMA Negeri 2 Singaraja tahun pelajaran 2020/2021.

\section{METODE}

Penelitian ini merupakan penelitian pengembangan. Peneliti memilih model penelitian yang digunakan dalam penelitian pengembangan ini yaitu model Borg \& Gall. Peneliti memilih model penelitian Borg \& Gall didasarkan bahwa penelitian model Borg \& Gall ini tersusun secara terprogram dengan tahapan-tahapan penelitian yang sistematis dan terstruktur guna menghasilkan produk media pendikan yang layak untuk digunakan. Tahapan model penelitian pengembangan Borg \& Gall, yaitu: (1). tahap studi pendahuluan (pengumpulan data awal), (2). tahap perencanaan pengembangan, (3). tahap pengembangan produk media, (4). tahap uji validitas ahli dan revisi produk, (5) tahap validasi dan penyebaran produk media pembelajaran (Sutarti, T., \& Irawan, 2017). Penelitian pengembangan media pembelajaran PJOK berbasis audio visual pada materi shooting bolabasket ini prosedur pengembangan yang dilakukan sesuai dengan tahapn oleh Borg \& Gall. Namun untuk proses pengambilan data lapangan atau uji coba lapangan produk media tidak dapat terlaksana dikarenakan pandemi covid-19. Subjek uji coba dalam pengembangan media pembelajaran berbasis audio visual ini adalah tahap review dari para ahli yang terdiri dari ahli isi materi dosen S2 Pendidikan Olahraga Fakultas Olahraga dan Kesehatan Universitas Pendidikan Ganesha, ahli desain pembelajaran Dosen S2 Teknik Informatika Fakultas Teknik dan Kejuruan Universitas Pendidikan Ganesha, dan satu orang ahli media pembelajaran Dosen S2 Teknik Informatika Fakultas Teknik dan Kejuruan Universitas Pendidikan Ganesha.Penelitian pengembangan media pembelajaran ini mengumpulkan data menggunakan teknik analisis deskriptif kuantatif. Teknik analisis deskriptif kuantitatif ini digunakan untuk mengolah data yang diperoleh melalui angket kuisioner dalam bentuk deskriptif persentase. Untuk dapat memberikan keterangan dan pengambilan keputusan digunakan ketetapan Tabel 1.

Tabel 1. Konversi Tingkat Pencapaian Skala 5

\begin{tabular}{ccc}
\hline Tingkat Pencapaian (\%) & Kualifikasi & Keterangan \\
\hline $91-100$ & Sangat Baik & Tidak Perlu Direvisi \\
$76-90$ & Baik & Tidak Perlu Direvisi \\
$66-75$ & Cukup & Revisi Produk \\
$56-65$ & Kurang & Revisi Produk \\
$1-55$ & Sangat Kurang & Mengulang Kembali \\
\hline
\end{tabular}

\section{HASIL DAN PEMBAHASAN}

Pengembangan Media Pembelajaran PJOK Berbasis Audio Visual Pada Materi Shooting Bolabasket dilaksanakan sesuai dengan tahapan model penelitian pengembangan Borg \& Gall, yang dimulai dengan (1). tahap studi pendahuluan (pengumpulan data awal), (2). tahap perencanaan pengembangan, (3). tahap pengembangan produk media, (4). tahap uji validitas ahli dan revisi produk, (5) tahap validasi dan penyebaran produk media pembelajaran (Sutarti, T., \& Irawan, 2017). Tahap pengumpulan data awal, kegaitan yang dilakukan pada tahap pertama adalah mengumpulkan data awal dengan cara melakukan observasi serta wawancara secara langsung. Agar peneliti mengetahui kebutuhan belajar dilakukan pada siswa agar media yang dikembangkan sesuai dengan kebutuhan siswa. Seta untuk mengetahui kendalakendala yang ditemui guru dan siswa dalam proses pembelajaran. Namun pada penelitian ini proses pengambilan data lapangan tidak dapat terlaksana dikarenakan pandemi covid-19. Peneliti mencari. Tahap kedua yaitu tahap perencanaan pengembangan, yang dilakukan adalah merancang naskah media audio visual pembelajaran. Pada tahap ini dilakukan penyusunan garis besar isi media video, penyusunan jabaran materi. Tahap ketiga adalah tahap pengembangan produk. Tahap pengembangan yaitu tahap awal yang dilakukan untuk membuat media. Hal yang dilakukan dalam membuat media yaitu dengan menyusun KD, merumuskan indikator, menetapkan materi, mengumpulkan video-video, mengembangkan 
animasi-animasi yang berhubungan dengan materi shooting pada olahraga bola basket untuk digunakan didalam media. Tahap keempat adalah tahap validasi.

Validasi ini dilakukan untuk mengetahui kelayakan dari media tersebut yang dilakukan oleh validator yang berjumlah 4 validator, yaitu 2 ahli media dan 2 ahli materi. Adapaun hasil validasi oleh para hli dapat dilihat pada Tabel 2 .

Tabel 2. Hasil Penilaian Para Ahli

\begin{tabular}{ccc}
\hline Ahli & Kualifikasi & Presentase \\
\hline Ahli Isi/Materi Pembelajaran & $94,6 \%$ & Sangat Baik \\
Ahli Media Pembelajaran & $92 \%$ & Sangat Baik \\
Ahli Desain Media Pembelajaran & $93 \%$ & Sangat Baik \\
\hline
\end{tabular}

Penelitian pengembangan ini menghasilkan produk media pembelajaran PJOK berbasis audio visual pada materi shooting bolabasket yang ditujukan untuk peserta didik kelas XI SMA Negeri 2 Singaraja guna membantu peserta didik dalam memahami materi yang disampaikan dalam proses pembelajaran daring disekolah. Hasil dari penelitian menunjukan bahwa validitas media pembelajaran berbasis audio visual yang dikembangkan ditinjau dari aspek ahli isi/materi pembelajaran berada pada kategori sangat baik dengan presentase sebesar $94,6 \%$. Adapun beberapa saran perbaikan yang diberikan oleh ahli isi/materi pembelajaran yaitu: 1) Pada tahap awalan gerakan, urutan pelaksanaan terbalik. Dimulai dari posisi lalu kebadan. Silahkan Perbaiki tahapan pelaksanaan gerakan sesuai urutan. (2) Pada tahap pelaksanaan: (a) Tambahkan penjelasan gerakan lecutan tangan saat melempar bola. (b) Perbaiki penjelasan gerakan kedua tangan lurus kedepan menjadi satu tangan lurus kedepan. Hasil penilian dari aspek ahli media pembelajaran berada pada kategori sangat baik dengan perolehan presentase sebesar $92 \%$. Saran perbaikan yang diberikan oleh ahli desain media pembelajaran yaitu pada tahap pemanasan bisa ditambahkan nama gerakan pelaksanaan. Hasil penilaian dari aspek ahli desain media pembelajaran berada pada kategori sangat baik dengan perolehan presentase sebesar 93\%. Adapun beberapa saran perbaikan yang diberikan oleh ahli desain media pembelajaran yaitu: (1) kualitas video bisa ditingkatkan diatas 720p. (2) Terkait teknis pengambilan gambar perlu stabilizier agar video tidak goyang.

Tahap terakhir adalah tahap validasi dan penyebaran produk media pembelajaran. Tahap ini yang dilakukan yaitu uji coba kelompok kecil dan uji coba kelompok besar, untuk mengukur bagaimana tanggapan dan penilaian pengguna setelah menggunakan produk media pembelajarn audiovisual. Dalam penerapan produk atau uji coba hal yang harus dilakukan adalah berkoordinasi dengan guru yang mengajar sehingga terjadi kolaborasi yang baik antara peneliti selaku pengembang dan guru (N. L. A. M. Dewi, 2017). Namun karena adanya pandemic covid 19 proases uji coba tidak dapat terlaksana mengharuskan seluruh peserta didik dan seluruh instansi pendidikan belajar dan bekerja dirumah. Oleh karena itu proses pembelajarn yang dilaksanakn secara daring harus dapat menumbuhkan minat dan motivasi siswa untuk belajar guna tercapainya tujuan pembelajaran.

Kesuksesan pembelajaran ditentukan oleh keterlibatan aktif pembelajar dalam lingkungan belajar (Gregorius, 2017). Pembelajaran yang kurang memaksimalkan penggunaan media pembelajaran dapat mengurangi minat dan peran peserta didik dalam pembelajaran (Farman \& Chairuddin, 2020; E. Setiawan \& Rizki, 2018). Oleh karena itu pada proses pembelajaran guru seharusnya tidak hanya menguasai materi akan tetapi juga harus pandai memanfaatkan media dalam menunjang pembelajaran yang akan dilakukan, karena materi akan lebih mudah tersampaikan. Serta guru hendaknya mampu memilih media yang tepat dan sesuai dengan materi yang akan disampaikan. Untuk mewujudkan proses belajar mengajar agar yang lebih efektif maka diperlukan suatu media yang sesuai dengan karakter peserta didik, mata pelajaran yang disampaikan, suasana dan prasarana penunjang. Penggunaan media pengajaran sangat penting bagi proses belajar dan mengajar. Dikatakan demikian karena media pengajaran sangat membantu pendidik atau pengajar dalam memberikan pengajaran secara maksimal, efektif, serta efisien (Budi \& Prihanto, 2014; Fauzi \& Rosliyah, 2020). Dengan perangkat pembelajaran yang baik akan menuntun siswa untuk dapat meningkatkan hasil belajar dengan baik. Penggunaan media dalam pembelajaran merupakan salah satu cara untuk meningkatkan ketertarikan siswa dalam mengikuti pembelajaran. Media pembelajaran merupakan sarana pendidikan yang dapat digunakan sebagai perantara dalam proses pembelajaran, dengan media pembelajaran siswa mampu mendapatkan pengetahuan, keterampilan, atau sikap untuk tercapainya tujuan pembelajaran (Rohmawati, Bahtiar, \& Dayat, 2019). Penggunaan media pembelajaran dapat merangsang perhatian dan minat dalam belajar (Pandaleke, Munzil, \& Sumari, 2020). Dalam proses pembelajaran, media memiliki fungsi sebagai pembawa informasi dari sumber (guru) kepada penerima (siswa) guna mencapai tujuan pembelajaran (Sudarto, Nugrahani, \& Susanto, 2019). 
Untuk itu pada materi passing bola basket diperlukan pembelajaran yang menarik dan memudahkan peserta didik untuk memahami proses pembelajaran penjasorkes. Dalam rangka usaha untuk meningkatkan penguasaan keterampilan teknik dasar, banyak media atau alat bantu latihan yang dapat digunakan. Ditambah dengan perkembangan teknologi saat ini membuat media pembelajaran berkembang dari waktu kewaktu. Media pembelajaran memiliki banyak ragam seperti media berbentuk audio, visual, audio visual (Ashfahany et al., 2017; Pandaleke, Munzil, \& Sumar, 2020). Media audiovisual merupakan salah satu media yang dapat digunakan untuk pembelajaran olahraga. Media audio visual adalah media penyampai informasi yang memiliki krakteristik suara dan gambar (Arwanda, Kresnapati, \& Widyatmoko, 2021; Fikriyah, 2015). Media audiovisual mampu memudahkan guru dalam menjelaskan gerak pola langkah permainan olahraga dan siswa juga lebih mudah memahami penjelasan dari guru, sehingga pada saat pembelajaran di lapangan siswa lebih mudah untuk mempraktikkan gerakan pola langkah yang benar (Widyalaksono, Mashuri, \& Lusianti, 2020). Media Audiovisual akan mempermudah guru dalam menyampaikan pembelajaran, agar pembelajaran lebih efektif diperlukan alat bantu lain, alat bantu itu berupa alat bantu pandang (visual) atau alat bantu dengar (audio). Dalam media pembelajaran audio visual kedua hal tersebut sangat dominan karena media ini menggabungkan kedua hal tersebut (Yuliana, Astra, \& Adi, 2017). Media audio visual akan menjadikan penyajian bahan ajar kepada siswa semakin lengkap dan optimal. Media pembelajaran audio visual sebagai salah satu produk multimedia dewasa ini begitu populer, karena mampu mempresentasikan informasi secara lebih menarik kepada siswa. Salah satu kelebihan media audio visual yaitu memiliki penggambaran yang bersifat tiga dimensi sehingga peserta didik dapat melihat melihat dengan jelas tanpa harus membayangkan (Wati, 2016). Media audiovisual digunakan sebagai media yang menyajikan pengalaman yang konkrit melalui visualisasi dengan tujuan antara lain untuk memperkenalkan, memperkaya atau memperjelas konsep yang abstrak dan mendorong timbulnya kegiatan sasaran didik yang lebih lanjut. Media audiovisual ini merupakan salah satu sarana alternatif dalam melakukan pembelajaran daring. Dikarenakan kondisi saat pembelajaran daring berbeda dengan pembelajaran tatap muka di kelas, memerlukan lebih banyak kreativitas guru dalam merancang dan menerapkan media yang digunakan selama pembelajaran. Media audiovisual diyakini dan terpercaya lebih mampu menggairahkan animo siswa, karena sifatnya sendiri yang mudah dikemas dan lebih menarik siswa untuk mengikuti dengan suasana senang(Salsabila, Sofia, Seviarica, \& Hikmah, 2020).

Penelitian ini relevan dengan beberapa penelitian yang telah dilakukan sebelumnya, diantaranya 1) Penelitian oleh (Ramadhan, Yulianti, \& Henjilito, 2020; Simbolon, 2016) yang menunjukkan bahwa penerapan pembelajaran olahraga bolabasket mengunakan metode audio visual dapat memberikan kontribusi yang besar dan signifikan terhadap hasil belajar dribbling bolabasket.2) Penelitian oleh (Suryani \& Seto, 2021) yang menunjukkan bahwa dengan menggunakan media audiovisual dalam hal ini penggunaan video sangat berperan dan mempengaruhi daya ingat anak menerapkan pola hidup sehat tentang bagaimana cara anak untuk peduli dengan lingkungannya. 3) Penelitian oleh (Sulfemi, W. B., \& Mayasari, 2019) dengan judul Penerapan Model Pembelajaran Value Clarification Thenique Berbantuan Audio Visual menyimpulkan bahwa Penerapan Model Pembelajaran Value Clarification Thenique Berbantuan Audio Visual dapat meningkatkan motivasi peserta didik dalam proses belajar dan hasil belajar. 4) penelitian yang dilakukan oleh (Nosa \& Farida, 2018) yang menunjukkan bahwa media pembelajaran audio visual yang dihasilkan dinilai layak digunakan sebagai media pembelajaran matematika. Implikasi penelitian ini adalah sebagai berikut: 1) Pengembangan media pembelajaran dapat digunakan sebagai motivasi guru untuk menggunakan dan menciptakan media pembelajaran, guna membantu dalam proses belajar-mengajar terutama untuk mata pelajaran Penjasorkes. 2) Pengembangan media pembelajaran dapat meningkatkan minat belajar siswa untuk menambah pengetahuan dan pengalaman dibidang akademis maupun nonakademis.

\section{SIMPULAN DAN SAwRAN}

Simpulan dari penelitian ini yaitu penilaian dari ahli media pembelajaran berada pada kategori sangat baik dengan presentase sebesar 92\%. Hasil penilaian dari ahli desain media pembelajaran berada pada kategori sangat baik dengan presentase sebesar 93\%. Sehingga dapat disimpulkan bahwa media pembelajaran PJOK berbasis audio visual pada materi shooting bolabasket kelas XI SMA Negeri 2 Singaraja Tahun Pelajaran 2020/2021 dikatakan layak untuk digunakan dalam proses pembelajaran. Adapun saran yang dapat disampaikan kepada berbagai pihak yang bersangkutan yakni Bagi peserta didik dengan adanya media pembelajaran PJOK berbasis audio visual pada materi shooting bolabasket ini peserta didik di harapkan dapat terus belajar secara mandiri,bagi guru hendaknya menciptakan proses pembelajaran PJOK secara daring lebih inovatif dalam mengembangkan media, bagi sekolah disarankan agar menyimpan media PJOK berbasis audio visual pada materi shooting bolabasket kelas XI ini dalam 
bentuk MP4 dengan baik agar dapat dijadikan sebagai salah satu sumber belajar, bagi peneliti lain disarankan agar hasil penelitian pengembangan ini mampu di jadikan sebagai sumber yang relevan.

\section{DAFTAR RUJUKAN}

Adresta, R. A., \& Candra, O. (2020). Upaya Meningkatkan Hasil Belajar Shooting Free Throw Bola Basket Melalui Media Audio Visual. Jurnal Muara Olahraga, 2(2), 259-269. Retrieved from http://ejournal.stkip-mmb.ac.id/index.php/pjkr/article/view/311.

Arwanda, N. P., Kresnapati, P., \& Widyatmoko, F. A. (2021). Pengaruh Penggunaan Media Audio Visual Terhadap Hasil Belajar Dribble Bola Basket Kelas Xi Sma Negeri 15 Semarang Tahun Ajaran 2020. Journal of Physical Activity and Sports, 2(1), 55-63. https://doi.org/doi.org/10.53869/jpas.v2i1.82.

Ashfahany, F. A., Adi, S., \& Hariyanto, E. (2017). Bahan Ajar Mata Pelajaran Pendidikan Jasmani Olahraga Dan Kesehatan Dalam Bentuk Multimedia Interaktif Untuk Siswa Kelas Vii. Jurnal Pendidikan: Teori, Penelitian, Dan Pengembangan, 2(2), 261 - 267. https://doi.org/10.17977/jp.v2i2.8540.

Budi, B. A. S., \& Prihanto, J. B. (2014). Penggunaan Media Audiovisual Dengan Media Gambar Terhadap Hasil Belajar Shooting Bola Basket. Jurnal Pendidikan Olahraga Dan Kesehatan, 2(3), 612-616.

Candra, O. (2017). Pengaruh Metode Kooperatif Terhadap Keterampilan Lay Up Shoot Bola Basket Pada Siswa Puteri Kelas VIII Di SMP Negeri 9 Pekanbaru. Journal Sport Area, 2(1), 45-52. https://doi.org/10.25299/sportarea.2017.vol2(1).452.

Dewi, N. L. A. M. (2017). Pengembangan Multimedia Interaktif Teknik Dasar Bulutangkis Pada Mata Pelajaran Pendidikan Jasmani Olahraga Dan Kesehatan Kelas VIII SMP Negeri 3 Singaraja, 8(2).

Dewi, W. A. F. (2020). Dampak Covid-19 Terhadap Implementasi Pembelajaran Daring Di Sekolah Dasar. Jurnal Ilmu Pendidikan, 2(1), 55-61. https://doi.org/https://doi.org/10.31004/edukatif.v2i1.89.

Farman, \& Chairuddin. (2020). Pengembangan Media E-Learning Berbasis Edmodo Pada Materi Teorema Pythagoras. AKSIOMA: Jurnal Program Studi Pendidikan Matematika, 9(4), 872-882. https://doi.org/10.24127/ajpm.v9i4.3114.

Fatoni, R. A., Suroto, \& Indahwati, N. (2017). Pengaruh aktivitas fisik program gross motor skill terhadap indeks massa tubuh dan tingkat kebugaran jasmani. MULTILATERAL: Jurnal Pendidikan Jasmani Dan Olahraga, 1(1-10).

Fauzi, H. N., \& Rosliyah, Y. (2020). Persepsi Pembelajar terhadap Media Kamus Tematik Berbasis Web bagi Pembelajar Kosakata bahasa Jepang Tingkat Dasar. CHI'E: Jurnal Pendidikan Bahasa Jepang, 8(1), 25-32. https://doi.org/10.15294/chie.v8i1.35752.

Febryanto, F. N. (2015). Pembelajaran Lay Up Shoot Menggunakan Media Audio Visual Basic Lay Up Shoot Untuk Meningkatkan Hasilbelajar Lay Up Shoot Pada Siswa Kelas Viiia Smp Kanisius Pati Tahun 2013/2014. Journal of Physical Education, Sport, Health and Recreations, 4(1), 1509-1521. https://doi.org/10.15294/active.v4i1.4548.

Fikriyah. (2015). Media Berbasi Proyek Disertai Media Audio Visual Dalam Pembelajaran Fisika di SMA N 4 Jember. Jurnal Pembelajaran Fisika, 4(2), 181 - 184.

Gregorius, R. M. (2017). Performance of Underprepared Students in Traditional Versus Animation -Based Flipped -Classroom Settings. Chemistry Education Research and Practice, 18(4), 841-848. https://doi.org/10.1039/c7rp00130d.

Hanief, Y. N., Mashuri, H., \& Subekti, T. B. A. (2018). Meningkatkan Hasil Belajar Passing Bawah Bolavoli melalui Permainan 3 on 3 pada Siswa Sekolah Dasar. Jurnal Pendidikan Jasmani Dan Olahraga JPJO, 3(2), 161-166. https://doi.org/10.17509/jpjo.v3i2.12414.

Heri Rustanto. (2017). Meningkatkan Pembelajaran Shooting Bola Basket Dengan Menggunakan Media Gambar. Jurnal Pendidikan Olahraga, 6(2), 75 - 86. https://doi.org/10.31571/jpo.v6i2.668.

Hidayati, F. F. (2016). Karanglewas Kidul Kecamatan Karanglewas Skripsi Program Studi Pendidikan Guru Madrasah Ibtidaiyah.

Husmah, Pantiwati, Y., Restian, A., \& Sumaryono, P. (2016). Belajar dan Pembelajaran. Malang: Universitas Muhammadiyah Malang.

Iqbal, M. (2015). Hubungan Antara Daya Ledakototlengan, Kelentukan Pinggang Dan Motivasi Berprestasi Terhadap Keterampilan Lempar Lembing. Multilateral : Jurnal Pendidikan Jasmani Dan Olahraga, 14(1), 21-35. https://doi.org/10.20527/multilateral.v14i1.2467.g2168.

Jalil, M., Ngabekti, S., \& Susilowati, S. M. E. (2016). Pengembangan Pembelajaran Model Discovery Learning Berbantuan Tips Powerpoint Interaktif Pada Materi Interaksi Makhluk Hidup Dengan Lingkungan. Jurnal Refleksi Edukatika, 6(2), 130-137. https://doi.org/10.24176/re.v6i2.604.

Khozain, N., \& Mumaisaroh. (2020). Pengaruh Penggunaan Media Video Terhadap Hasil Belajar Peserta Didik Mata Pelajaran Aqidah Akhlak. Edukasia: Jurnal Pendidikan Dan Pembelajaran, 1(2), 331- 
346. Retrieved from http://jurnaledukasia.org/index.php/edukasia/article/view/31.

Lesmana, K. Y. P. (2014). Pentingnya Olahraga dan Kesehatan Gizi Bagi Keluarga dan Olahragawan. Prosiding Seminar Nasional MIPA, 373-388.

Mashuri, H. (2017). Persepsi Siswa Terhadap Pembelajaran Guru Pendidikan Jasmani Di Sma Muhammadiyah Kediri. Jurnal Pembelajaran Olahraga, 3(1), 1-10. Retrieved from https://ojs.unpkediri.ac.id/index.php/pjk/article/view/681/505.

Nosa, D. E., \& Farida. (2018). Aplikasi Wingeom dan Camtasia Studio untuk Pembuatan Media Pembelajaran Audio Visual. Desimal: Jurnal Matematika, 1(2), 127-137. https://doi.org/10.24042/djm.v1i2.2272.

Pandaleke, M., Munzil, \& Sumar. (2020). Pengembangan Media Pelajaran Kelas Flipped Berbasis Animasi untuk Mening katkan Pemahaman Konsep Kimia. Jurnal Pendidikan: Teori, Penelitian, Dan Pengembang, 5(3), 387 - 394. https://doi.org/10.17977/jptpp.v5i3.13293.

Pandaleke, M., Munzil, \& Sumari. (2020). Pengembangan Media Pelajaran Kelas Flipped Berbasis Animasi untuk Mening katkan Pemahaman Konsep Kimia. Jurnal Pendidikan: Teori, Penelitian, Dan Pengembang, 5(3), 387 - 394. https://doi.org/10.17977/jptpp.v5i3.13293.

Pane, A., \& Dasopang, M. D. (2017). Belajar Dan Pembelajaran. FITRAH Jurnal Kajian Ilmu-Ilmu Keislaman, 3(2), 333-352. Retrieved from. padangsidimpuan.ac.id/index.php/F/article/view/945/795.

Parwati, N., Suryawan, P., \& Apsari, R. (2018). Belajar dan Pembelajaran (Cetakan Ke). Depok: Rajawali Pers.

Prameswara, W. (2019). Hubungan Antara Kedisiplinan Dengan Hasil Belajar Siswa SMA Negeri 4 Sidoarjo Dalam Pembelajaran PJOK. Jurnal Pendidikan Olahraga Dan Kesehatan, 7(3), 237-240.

Putra, G. H., Kanca, N., \& Suwiwa, G. (2017). Pengembangan Media Video Pembelajaran Dengan Model Addie Pada Materi Passing Bola Voli. Jurnal Pendidikan Jasmani, Olahraga Dan Kesehatan Undiksha, 7(1).

Ramadhan, F., Yulianti, M., \& Henjilito, R. (2020). Penerapan media audio visual dalam meningkatkan hasil belajar dribble bolabasket. Edu Sportivo Indonesian Journal of Physical Education, 1(1), 50-59. https://doi.org/10.25299/es:ijope.2020.vol1(1).5122.

Rohmawati, D., Bahtiar, R. S., \& Dayat, T. (2019). Efektivitas Penggunaan Media Papan Waktu Pada Pembelajaran Penghitungan Waktu Bagi Siswa Kelas Iii Sekolah Dasar. Urnal Bidang Pend Idikan Dasar (JBPD), 3(1), 14-23. https://doi.org/10.21067/jbpd.v3i1.2857.

Rupawati, D., Noviani, L., \& Ariyanto, J. (2017). Penerapan Media Pembelajaran Audio Visual. Jurnal Pendidikan Ekonomi Manajemen Dan Keuangan, 1(1), 21-30. https://doi.org/10.26740/jpeka.v1n1.p21-30

Salsabila, U. H., Sofia, M., Seviarica, H. P., \& Hikmah, M. N. (2020). Urgensi Penggunaan Media Audiovisual Dalam Meningkatkan Motivasi Pembelajaran Daring Di Sekolah Dasar. INSANIA : Jurnal Pemikiran Alternatif Kependidikan, 25(2), 284-304. https://doi.org/10.24090/insania.v25i2.4221.

Sampurno, H. W., \& Qohhar, W. (2020). Perbandingan Gaya Mengajar Terhadap Hasil Shooting Bola Basket. PHYSICAL ACTIVITY JOURNAL, 1(2), 142-152. https://doi.org/10.2088 4 /1.paju.2020.1.2.2493.

Saputra, T. Y., Kanca, I. N., \& Lesmana, K. Y. P. (2017). Implementasi Kooperatif NHT Untuk Meningkatkan Aktivitas dan Hasil Belajar Passing Bolabasket. E-Journal PJKR Universitas Pendidikan Ganesha, $8(2)$.

Setiawan, A. (2017). Belajar Dan Pembelajaran. FITRAH:Jurnal Kajian Ilmu-Ilmu Keislaman, 3(2), 333. https://doi.org/10.24952/fitrah.v3i2.945.

Setiawan, A., \& Rahmat, A. (2018). Pengaruh Pembelajaran Bola Tangan Terhadap Perilaku Sosial Siswa. Jurnal Pendidikan Jasmani Dan Olahraga, 3(1), 89-94. https://doi.org/10.17509/ jpjo.v3i1.10188.

Setiawan, E., \& Rizki, S. (2018). Pengembangan Bahan Ajar Barisan Dan Deret Matematika Berbasis Multimedia Interaktif. AKSIOMA, 7(2), 465-472.

Simbolon, S. N. (2016). Upaya Peningkatan Hasil Belajar Dribbling Bola Basket Melalui Penerapan Media Pembelajaran Audio Visual Pada Siswa Kelas VII - 2 SMP Negeri 5 Lima Puluh Kabupaten Batubara Tahun Ajaran 2 014/2015. Jurnal Pendidikan Dan Olahraga, 1(3), 277 - 318.

Sokheh, M., Wahjoedi, \& Suwiwa, I. G. (2017). Pengembangan Media Video Pembelajaran Dengan Model Addie Materi Passing Bola Basket. E-Journal PJKR, Universitas Pendidikan Ganesha Pendidikan Jasmani, Kesehatan, Dan Rekreasi, 8(2), 1-11.

Sudarto, Nugrahani, F., \& Susanto, H. A. (2019). Pengembangan Bahan Ajar Media Audio Visual Berbasis Powerpoint Untuk Menumbuhkan Minat Membaca Permulaan Sekolah Dasar. Page 1 Stilistika, $5(1)$.

Sudirjo, E., Susilawati, D., Lengkana, A. S., \& Alif, M. N. (2019). Mentoring and Training of Body Balance on 
Primary, 18(1), 93-101.

Sulfemi, W. B., \& Mayasari, N. (2019). Peranan Model Pembelajaran Value Clarification Technique Berbantuan Media Audio Visual Untuk Meningkatkan Hasil Belajar IPS. Jurnal Pendidikan, 20(1), 53. https://doi.org/10.33830/jp.v20i1.772.2019.

Suranti, N. M. Y., Gunawan, \& Sahidu, H. (2016). Pengaruh Model Project Based Learning Berbantuan Media Virtual Terhadap Penguasaan Konsep Peserta didik pada Materi Alat-alat Optik. Jurnal Pendidikan Fisika Dan Teknologi, 2(2), 73-79. https://doi.org/10.29303/jpft.v2i2.292.

Suryani, L., \& Seto, S. B. (2021). Penerapan Media Audio Visual untuk Meningkatan Perilaku Cinta Lingkungan pada Golden Age. Jurnal Obsesi : Jurnal Pendidikan Anak Usia Dini, 5(1), 900-908. https://doi.org/10.31004/obsesi.v5i1.601.

Sutarti, T., \& Irawan, E. (2017). Kiat Sukses Meraih Hibah Penelitian Pengembangan. Yogyakarta: CV. Budi Utama.

Wati, E. R. (2016). Ragam Media Pembelajaran. Yogyakarta: Kata Pena.

Widyalaksono, P., Mashuri, H., \& Lusianti, S. (2020). Penerapan Media Audio Visual Untuk Meningkatkan Hasil Belajar Gerak Dasar Pola Langkah Pencak Silat Sekolah Dasar. Gelanggang Pendidikan Jasmani Indonesia, 4(1), 8-17. https://doi.org/10.17977/um040v4i1p8-17.

Yuliana, Peni \& Syam Tuasikal, A. R. (2020). Pengaruh Metode Bagian Pada Hasil Shooting Bola Basket. Jurnal Pendidikan Olahraga Dan Kesehatan, 8(1), 59 - 62. Retrieved from. https://ejournal.unesa.ac.id/index.php/jurnal-pendidikan-jasmani/article/view/32448.

Yuliana, A. I., Astra, I. K. B., \& Adi, I. P. P. (2017). Pengaruh Penggunaan Media Audio Visual Terhadap Hasil Belajar Teknik Dasar Passing Bola Basket. Jurnal Pendidikan Jasmani,Olahraga Dan Kesehatan $\begin{array}{ccr}\text { Undiksha, } & 5(2) . & \text { Retrieved } \\ \text { https://ejournal.undiksha.ac.id/index.php/JJP/article/view/14833. }\end{array}$ 